\title{
Synthesis of New 3-Substituted Quinazolin-4(3H)-one Compounds Via Linking of Some Five-Membered Ring Heterocyclic Moieties with Quinazolin-4(3H)-one Nucleus
}

\author{
Mohammed A. Al-Iraqi ${ }^{* 1}$, Rand A. Saad-Aldeen ${ }^{2}$ \\ ${ }^{1}$ Department of Biology, College of Science, University of Mosul, Mosul, Iraq \\ ${ }^{2}$ Department of Biology, College of Education of Girl, University of Mosul, Mosul, Iraq \\ E-mail: ${ }^{1 *}$ maanaa5463@gmail.com,${ }^{2}$ palm2017tree@gmail.com
}

(Received August 07, 2020; Accepted October 04, 2020; Available online March 01, 2021)

DOI: 10.33899/edusj.2020.127904.1101, (C) 2020, College of Education for Pure Science, University of Mosul.

This is an open access article under the CC BY 4.0 license (http://creativecommons.org/licenses/by/4.0/).

\begin{abstract}
In this research new compounds containing quinazolin-4(3H)-one nucleus linked to heterocyclic moieties were synthesized using ethyl (4'-oxoquinazolin-3'-yl) acetate (2) as a synthon. This compound was synthesized via 4-quinazolinone's (1) reaction with ethyl chloroacetate in the existence of $\mathrm{K}_{2} \mathrm{CO}_{3}$ as a base and acetone as a solvent. The ethyl $\alpha$-(4'-oxoquinazolin-3'-yl) acetate (2) was converted to the corresponding hydrazide through its reaction with hydrazine hydrate $(85 \%)$. Compound (3) was reacted with two of acyl chlorides to synthesize the diacyl hydrazine compounds $(4,5)$. The compound (5) was cyclized to the corresponding 1,3,4-oxadiazole (6) in presence of phosphorous oxychloride. The formyl derivative (7) of the hydrazide (3) was synthesized via its reaction with formic acid and consequently cyclized by phosphorous oxychloride to the corresponding 1,3,4-oxadiazole (8). The hydrazide (3) was also converted to the thiosemicarbazide derivative (9) by its reaction with ammonium thiocyanate under acidic conditions. Whereas other substituted thiosemicarbazide derivatives (10-12) were synthesized by the reaction of hydrazide (3) with organic isothiocyanate compounds. The resultant compounds $(11,12)$ were cyclized under basic conditions (4\% sodium hydroxide solution) to give 1,3,4-triazole-2-thiole derivatives $(13,14)$, whereas the cyclization of compounds (10-12) was performed under the acidic medium (conc. $\mathrm{H}_{2} \mathrm{SO}_{4}$ ) to give 2 substituted amino-1,3,4-thiadiazoles (15-17). On the other side, the hydrazide's (3) reaction with isocyanate compounds affords the semicarbazide compounds $(18,19)$. These compounds were cyclized under the basic condition to afford 1,3,4-triazol-2-ol compounds $(20,21)$. The structures of the synthesized compounds were corroborated depending on the physical and spectral data.
\end{abstract}

keywords: quinazolinone; oxadiazole; thiadiazole; triazole; carbohydrazide.

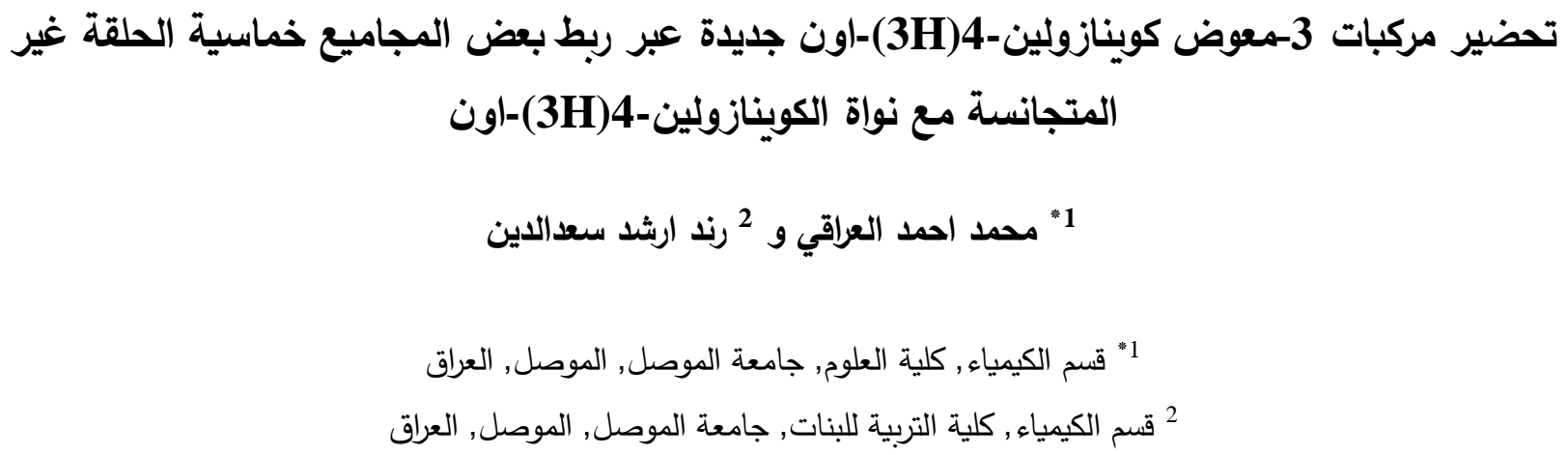


يتضمن البحث تحضير مركبات جديدة تحتوي على نواة الكوينازولين-3H(3H)-أون مرتبطة بمجاميع حلقية غير متجانسة باستخدام

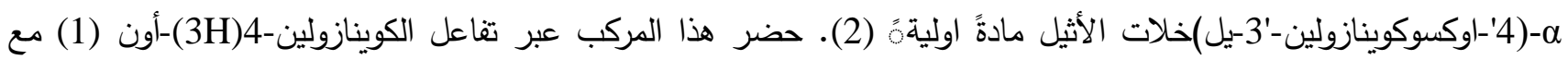

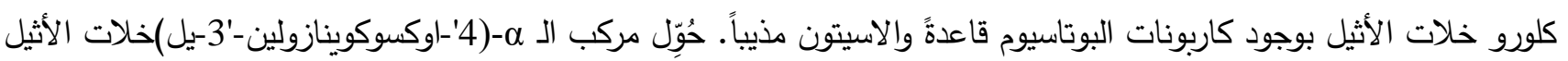

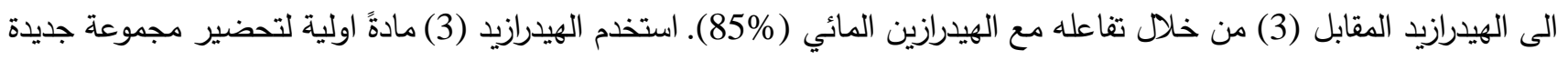

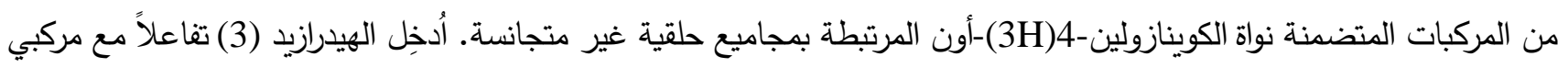
كلوريد الأسيل لتحضير مركبي الثنائي أسيل هيدرازين (4,5)، ومن ثم تم حولقة المركب (5) بوجود أوكسي كلوريد الفسفور الى مركب الفي الـ 4,3,1-اوكسادايازول (6). كما استخدم الهيدرازيد (3) لتحضير مشتق الفورميل هيدرازيد (7) الذي يتحولق بوجود أوكسي كلوريد الفنفور الى الـ 4,3,1-أوكسادايازول (8). كذلك حوّل الهيرازيد (3) الى مركب الثايوسميكاربازيد (9) بتفاعله مع ثايوسيانات الأمونيوم تحت ظروف حامضية. بينما حضرت مشتقات الثايوسميكاربازيد (12-10) بتفاعل الهيدرازيد (3) مع الثايوسيانات العضوية. تم حولقة المركبين (11,12) تحت ظروف قاعدية (4\% من محلول هيدروكسيد الصوديوم) ليعطيان مركبي الـ 4,3,1-ترايازول-2-ثايول (13,14)

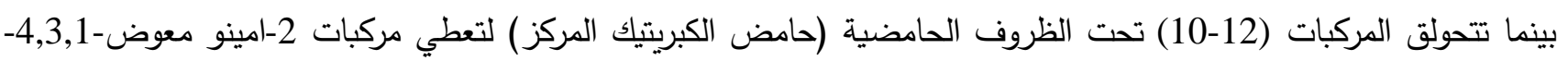
ثايادايازول (17-15). من ناحية اخرى, يتفاعل الهيدرازيد (3) مع الآيزوسيانات العضوية ليعطي مركبات السمي كاربازيد (19-18) التي تتحولق تحت الظروف القاعدية الى مركبات الـ 4,3,1-ترايازول -2-اول (20,21). شخصت الائرونسان تراكيب المركبات المحضرة اعتماداً على البيانات الفيزيائية والطيفية. الكلمات المفتاحية: الكوينازولينون؛ اوكسادايازول؛ ثايادايازول؛ ترايازول؛ كاربوهيدرازيد.

\section{INTRODUCTION}

There is a huge number of biologically active compounds that contains a heterocyclic core possessing various heteroatoms such as nitrogen, oxygen and sulfur. The biological importance of these compounds has drawn the attention of the chemists to synthesize interesting new derivatives containing heterocyclic moieties in order to improve their biological activity. Among these heterocyclic compounds is 4-quinazolinones which are of great heed owing to their discrete and wide biological activity and their importance in the pharmacological and medicinal fields, in addition to their diverse chemical applications. It has been found that the 4-quinazolinones own a broad spectrum of activity exemplified as anticancer [1-3], antifungal [4,5], antitumor [6-8], antipsychotic [9], antimicrobial [10], antioxidant [11,12], anti-HIV [14,15], anti-inflammatory and analgesic [16], antihypertensive [17] and anticonvulsant [18]. Furthermore, they were considered a fundamental part of many natural alkaloids $[19,20]$. On the other hand, it was found that many heterocyclic nuclei other than quinazoline-4(3H)-ones such as 1,3,4-oxadizole, 1,3,4-thiadiazole, and 1,3,4-triazole showed biological importance [21-23]. Because of the increase of the biological importance of the quinazoline- $4(3 \mathrm{H})$-one derivatives, new quinazoline- $4(3 \mathrm{H})$-one compounds were synthesized via linking of quinazoline-4(3H)-one nucleus with heterocyclic moieties at position 3 through a series of intermediates using ethyl $\alpha$-(4'-oxoquinazolin-3-yl)acetate as a synthon.

\section{EXPERIMENTAL}

Open capillary tubes were used to measure the melting points by Stuard-SMP30 melting point device. Microwave irradiation was performed by microwave oven with power output $900 \mathrm{~W}$. Infrared spectra were recorded as neat on Alfa Bruker ATR- FT.IR Co. Germany, 2003. Bruker Bio Spin 400 $\mathrm{MHz}$ spectrometer was used to record the ${ }^{1} \mathrm{H}$ and ${ }^{13} \mathrm{C}$ NMR spectra, using the deuterated DMSO as a solvent and TMS as an internal reference. 


\section{Synthesis of 4-Quinazolinone (1):}

Our previous published paper [24] was followed to synthesize this compound.

\section{Synthesis of 3-(ethoxycarbonylmethyl)-4-quinazolinone (2):}

A mixture of 4-quinazolinone $(0.01 \mathrm{~mole}, 1.46 \mathrm{~g})$ and ethyl chloroacetate $(0.015 \mathrm{~mole}, 1.83 \mathrm{~g})$ in $(20$ $\mathrm{ml})$ of dried acetone in presence of $\mathrm{K}_{2} \mathrm{CO}_{3}(2 \mathrm{~g})$ was refluxed for $(6 \mathrm{~h})$. The mixture was cooled and poured on ice-cooled water $(50 \mathrm{ml})$. The resultant solid material was separated by filtration then washed thoroughly with water. The whitey resultant solid material was recrystallized from ethanolwater (90:10) to give crystals with lustrous white laminates in $(86 \%)$ yield, m.p.61-63 ${ }^{\circ} \mathrm{C}$.

\section{Synthesis of 1-[a-(4'-oxoquinazolin-3'-yl) acetyl] hydrazine (3) [25-26]:}

In absolute ethanol (20 ml), compound (2) (0.01 mole, $2.3 \mathrm{~g})$ was dissolved then hydrazine hydrate $(85 \%)(0.02$ mole, $0.9 \mathrm{~g})$ was added gradually. The resultant mixture was refluxed for $(4 \mathrm{~h})$ then condensed under reduced pressure, followed by cooling to give a precipitated product. The resultant solid material was rinsed thoroughly with water, dried, then recrystallized using ethanol to give lustrous silvery crystals in a yield of $(84 \%)$ and its m.p. is $249-250{ }^{\circ} \mathrm{C}$.

\section{Synthesis of diacyl hydrazine compounds $(4,5)[27]$ :}

An acyl chloride ( 0.005 mole) was added slowly to a previously cooled and stirred solution of the hydrazide (3) ( 0.005 mole, $1.09 \mathrm{~g})$ in dry pyridine $(20 \mathrm{ml})$. After the completion of the addition, refluxing the mixture with stirring for $(4 \mathrm{~h})$ was carried out then the mixture was poured on ice-cooled water $(50 \mathrm{ml})$, followed by neutralization with $\mathrm{NaHCO}_{3}(10 \%)$. The resultant mixture was filtrated and the remaining solid material was washed thoroughly with water, then ethanol was used to recrystallize the products. The physical data of compounds 4,5 are listed in Table 1 .

Table 1: The physical data of compounds 4,5.

\begin{tabular}{|c|c|c|c|c|}
\hline Compd. No. & Ar & m.p. $\left({ }^{\circ} \mathbf{C}\right)$ & Yield (\%) & Color \\
\hline 4 & $\mathrm{ph}$ & $282-283$ & 76.5 & white \\
\hline 5 & $4-\mathrm{CH}_{3} \mathrm{ph}$ & $293-295$ & 84 & white \\
\hline
\end{tabular}

\section{Synthesis of 3-[\{5-(p-tolyl)-1,3,4-oxadiazol-2-yl\}methyl]-4-quinazolinone (6) [28]:}

A mixture of the diacyl hydrazine compound (5) (0.001 mole, $0.33 \mathrm{~g})$ and phosphorous oxychloride $(5 \mathrm{ml})$ was refluxed for $(4 \mathrm{~h})$, then poured on crushed ice $(50 \mathrm{~g})$. To the resultant solution, sodium bicarbonate solution (20\%) was used to neutralize the solution to a weakly basic solution to give a precipitate which was filtrated off, and finally recrystallized using ethanol as a solvent to give honeycolored crystals in a yield of (64\%) and its m.p. is $177-178{ }^{\circ} \mathrm{C}$.

\section{Synthesis of $N^{\prime}$-formyl-N'-[( $\alpha$-(4'-oxoquinazolin-3'-yl)acetyl] hydrazine (7) [29]:}

The hydrazide (3) (0.004 mole, $0.87 \mathrm{~g})$ was mixed with formic acid $(0.03$ mole, $10 \mathrm{ml})$, then the mixture refluxed for $(30 \mathrm{~min})$. The remaining formic acid was distilled under reduced pressure, then the residue was treated with petroleum ether to reach a yellow solid product in a yield of (74\%) and its m.p. is $133-134^{\circ} \mathrm{C}$.

\section{Synthesis of 3-[(1,3,4-oxadiazol-2-yl)methyl]-4-quinazolinone (8) [29]:}

A mixture of formyl compound (7) $(0.001$ mole, $0.024 \mathrm{~g})$ and $(5 \mathrm{ml})$ of phosphorous oxychloride was refluxed for $(6 \mathrm{~h})$, then poured on $(50 \mathrm{~g})$ of crushed ice. To the resultant solution, $\mathrm{NaHCO}_{3}$ solution (20\%) was added until the solution became weakly basic. The resultant precipitate was filtrated off, then recrystallized using ethanol as a solvent to give white crystals in a yield of (65\%) and its m.p. is $306{ }^{\circ} \mathrm{C}$. 
Synthesis of 1-[ $\alpha$-(4'-oxoquinazolin-3'-yl)acetyl]thiosemicarbazide (9) [30]:

A concentrated hydrochloric acid $(2 \mathrm{ml})$ was added to a mixture of the hydrazide (3) $(0.005$ mole, $1.09 \mathrm{~g})$ and ammonium thiocyanate $(0.015$ mole, $1.14 \mathrm{~g})$ in ethanol $(25 \mathrm{ml})$. The mixture was refluxed for $(4 \mathrm{~h})$, then the volatile materials were vaporized under vacuum. The residue was rinsed thoroughly with water, dried, then treated many times with petroleum ether until a white solid product formed in $72 \%$ yield, its m.p. is $214-216^{\circ} \mathrm{C}$.

\section{Synthesis of 1-[ $\alpha$-(4'-oxoquinazolin-3'-yl) acetyl]-4-(allyl / 4"'-chlorophenyl / n-butyl)} thiosemicarbazide (10-12) [31,32]:

A mixture of hydrazide (3) and the alkyl isothiocyanate $(0.005 \mathrm{~mole})$ in absolute ethanol $(15 \mathrm{ml})$ for compound (10) and in dry benzene $(15 \mathrm{ml})$ for compounds $(11 \& 12)$ was refluxed for $6 \mathrm{~h}$, then cooled, to give a precipitate. The precipitate was filtrated then recrystallized using ethanol as a solvent to afford compounds (10-12). Table 2 shows their physical properties.

Table 2: The physical data of compounds 10-12.

\begin{tabular}{|c|c|c|c|c|}
\hline Compd. No. & $\mathrm{R}$ & m.p $\left({ }^{\circ} \mathrm{C}\right)$ & Yield (\%) & Color \\
\hline 10 & $-\mathrm{CH}_{2} \mathrm{CH}=\mathrm{CH}_{2}$ & $221-223$ & 75.8 & Hazel \\
\hline 11 & $-\mathrm{Cl}$ & $270-272$ & 83.8 & White \\
\hline 12 & $-\left(\mathrm{CH}_{2}\right)_{3} \mathrm{CH}_{3}$ & $206-207$ & 75 & White \\
\hline
\end{tabular}

Synthesis of 3-[\{4-(p-chlorophenyl / n-butyl)-5-mercapto-4H-1,2,4-triazol-3-yl $\}$ methyl]-4quinazolinone $(13,14)$ [30]:

A solution of thiosemicarbazides $(10,12)(0.002$ mole $)$ in $20 \mathrm{ml}$ of sodium hydroxide solution $(4 \%)$ was refluxed for $3 \mathrm{~h}$ then cooled, filtered then the filtrate acidified with diluted hydrochloric acid to afford a precipitate. The solid material was separated by filtration and rinsed thoroughly with water. Recrystallization of resultant material from ethanol afforded the titled compounds. Table 3 illustrates some of their physical properties.

Table 3: The physical data of compounds 13, 14.

\begin{tabular}{|c|c|c|c|c|}
\hline Compd. No. & $\mathrm{R}$ & m.p. $\left({ }^{\circ} \mathrm{C}\right)$ & Yield (\%) & Color \\
\hline 13 & - & $308-309$ & 71 & Faint green \\
\hline 14 & $-\left(\mathrm{CH}_{2}\right)_{3} \mathrm{CH}_{3}$ & $170-173$ & 70 & Hazel \\
\hline
\end{tabular}

\section{Synthesis of 3-[\{5-(allyl / p-chlorophenyl / n-butyl- amino)-1,3,4-thiadiazol-2-yl\}methyl]-4-} quinazolinone (15-17) [30]:

To a previously cooled and stirred thiosemicarbazide (10-12) (0.001 mole), concentrated sulfuric acid was added slowly within $15 \mathrm{~min}$. The stirring was continued in the ice-bath for $6 \mathrm{~h}$, in addition to (24 h) at room temperature. Pouring the mixture on ice cooled water $(50 \mathrm{ml})$ afforded a precipitate which was separated by filtration. This resulted precipitate was washed thoroughly with $\mathrm{H}_{2} \mathrm{O}$ then dried. Recrystallization of the resultant solid using ethanol as a solvent afforded the titled compounds. Table 4 illustrates some of their physical properties. 
Table 4: The physical data of compounds 15-17.

\begin{tabular}{|c|c|c|c|c|}
\hline Compd. No. & $\mathrm{R}$ & m.p. $\left({ }^{\circ} \mathrm{C}\right)$ & Yield (\%) & Color \\
\hline 15 & $-\mathrm{CH}_{2} \mathrm{CH}=\mathrm{CH}_{2}$ & $190-192$ & 61 & Faint brown \\
\hline 16 & - & $174-176$ & 67 & Hazel \\
\hline 17 & $-\left(\mathrm{CH}_{2}\right)_{3} \mathrm{CH}_{3}$ & $184-186$ & 64 & Hazel \\
\hline
\end{tabular}

Synthesis of 4-(cyclohexyl / p-toluene sulfonyl)-1-[ $\alpha$-(4-oxoquinazolin-3(4H)yl)acetyl]semicarbazide $(18,19)[33]$ :

A mixture of the hydrazide (3) (0.004 mole, $0.87 \mathrm{~g})$ and isocyanate compound ( $0.004 \mathrm{~mole})$ in dry benzene $(15 \mathrm{ml})$ was refluxed for six hours. Evaporation of the solvent under reduced pressure resulted in a residue which was washed thoroughly with $\mathrm{H}_{2} \mathrm{O}$ and dried, then recrystallized using methanol to afford the semicarbazides $(18,19)$. Table 5 illustrates their physical properties.

Table 5: The physical data of compounds 18-19.

\begin{tabular}{|c|c|c|c|c|}
\hline Compd. No. & $\mathrm{R}$ & $\mathrm{m} . \mathrm{p}\left({ }^{\circ} \mathrm{C}\right)$ & Yield (\%) & Color \\
\hline 18 & - & $205-206$ & 83 & Off-white \\
\hline 19 & $-\mathrm{SO}_{2}-$ \\
\hline
\end{tabular}

Synthesis of 3-[\{4-(cyclohexyl / p-toluene sulfonyl)-5-hydroxy-4H-1,2,4-triazol-3-yl\}methyl]-4quinazolinone $(\mathbf{2 0 , 2 1})[30]$ :

These compounds where synthesized from the semicarbazides $(18,19)$ via the same procedure for synthesizing compounds $(13,14)$. Table 6 illustrates their physical properties.

Table 6: The physical data of compounds 20-21.

\begin{tabular}{|c|c|c|c|c|}
\hline Compd. No. & $\mathrm{R}$ & $\mathrm{m} . \mathrm{p}\left({ }^{\circ} \mathrm{C}\right)$ & Yield (\%) & Color \\
\hline 20 & - & $309-310$ & 70 & Brown \\
\hline 21 & $-\mathrm{SO}_{2}$ \\
\hline
\end{tabular}

\section{RESULTS AND DISCUSSION}

In this study, the strategy for preparation 4-quinazolinone derivatives (2-21) was depicted in scheme 1. 


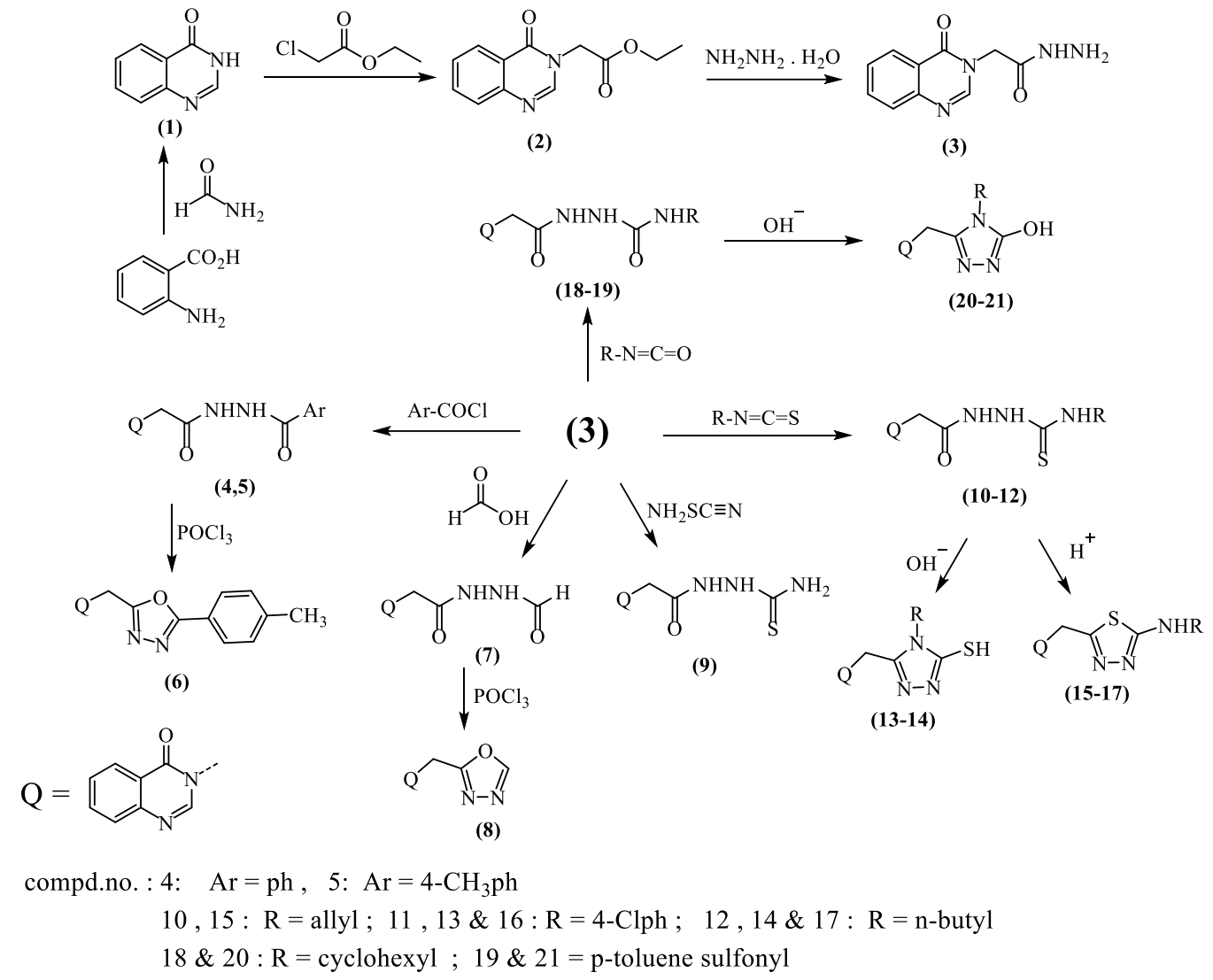

Scheme 1

The essential intermediate for the preparation of diverse heterocyclic compounds is the carbohydrazide derivative (3) of the quinazolin-4-(3H)-one (1). The carbohydrazide compound (3) was synthesized from the corresponding ester (2).

The first synthetic step is the synthesis of quinazolin-4- $(3 \mathrm{H})$-one (1) as starting material according to our previous paper [24] from the reaction of anthranilic acid ( 0.1 mole) with formamide $(0.5$ mole $)$, either by irradiation of the reaction mixture with microwave irradiation (green method) or by the conventional method. The quinazolin-4-(3H)-one (1) was converted to the corresponding ester (2) via alkylation process using ethyl chloroacetate in dried acetone in the existence of $\mathrm{K}_{2} \mathrm{CO}_{3}$ as an alkali material. The alkylation occurred at the nitrogen-3 rather than oxygen as identified from the spectral data. The appearance of characteristic spectral bands in the infrared spectrum at 1718 and $1679 \mathrm{~cm}^{-1}$ for the esteric and amido carbonyl $(\mathrm{C}=\mathrm{O})$ bond stretching respectively, supported the alkylation at $\mathrm{N}$ 3 position, and not at the oxygen of the quinazolinone moiety. Moreover, the infrared spectrum [34,35] of the ester (2) (Fig. 1) exhibited further bands at $1606 \mathrm{~cm}^{-1}$ for the aromatic $\mathrm{C}=\mathrm{C}$ bond stretching and at 1160 and $1234 \mathrm{~cm}^{-1}$ related to the symmetrical and asymmetrical $\mathrm{C}-\mathrm{O}$ bond stretching. 


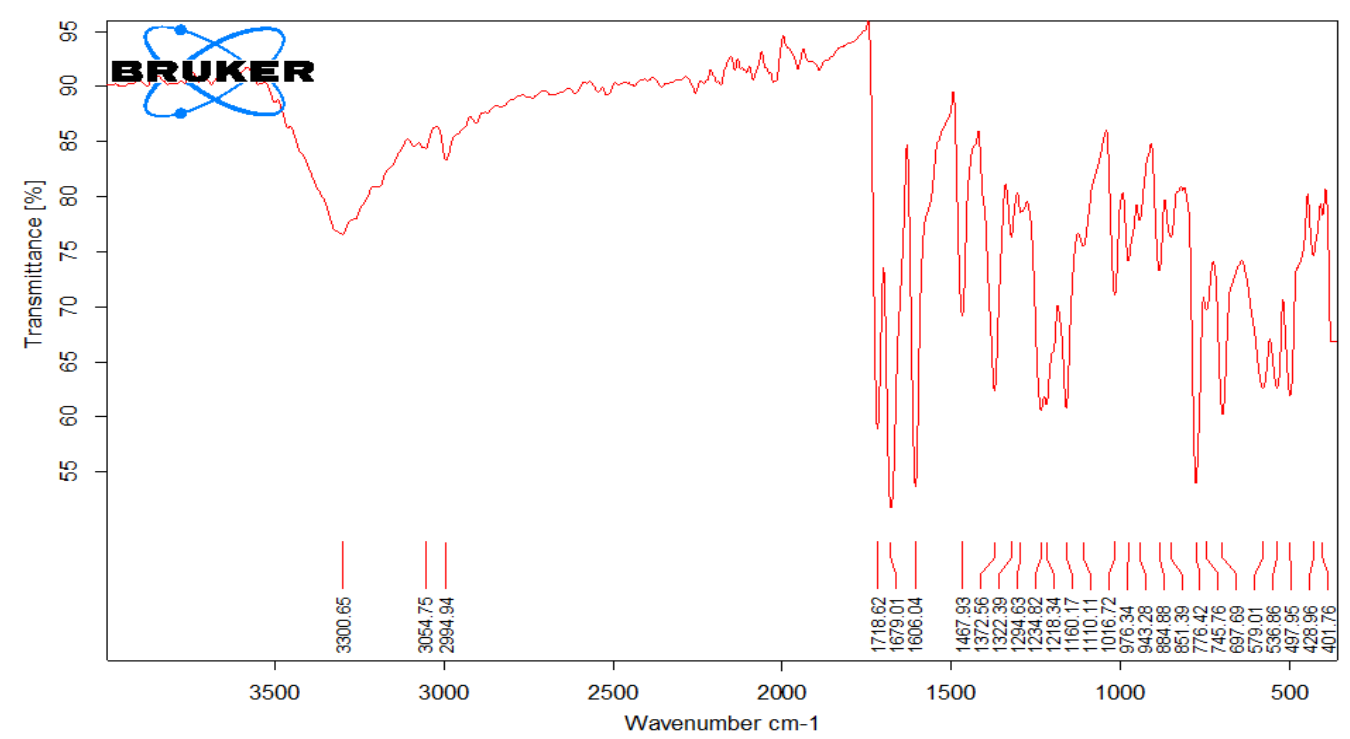

Fig 1: IR spectrum of compound 2.

The ${ }^{1} \mathrm{HNMR}$ spectrum (Fig. 2) [34,35] of compound (2) showed the following chemical shifts, $\delta(\mathrm{ppm})$, at: $4.18\left(\mathrm{q}, 2 \mathrm{H}, \mathrm{OCH}_{2} \mathrm{CH}_{3}\right), 1.22\left(\mathrm{t}, 3 \mathrm{H}, \mathrm{CH}_{3}\right), 4.84\left(\mathrm{~s}, 2 \mathrm{H}, \mathrm{N}-\mathrm{CH}_{2}\right), 7.60(\mathrm{t}, 1 \mathrm{H}, \mathrm{H} 6), 7.74(\mathrm{~d}, 1 \mathrm{H}, \mathrm{H} 5)$, 7.88 (t, 1H, H7), 8.17 (d, 1H, H8), 8.39 (s, 1H, H2).

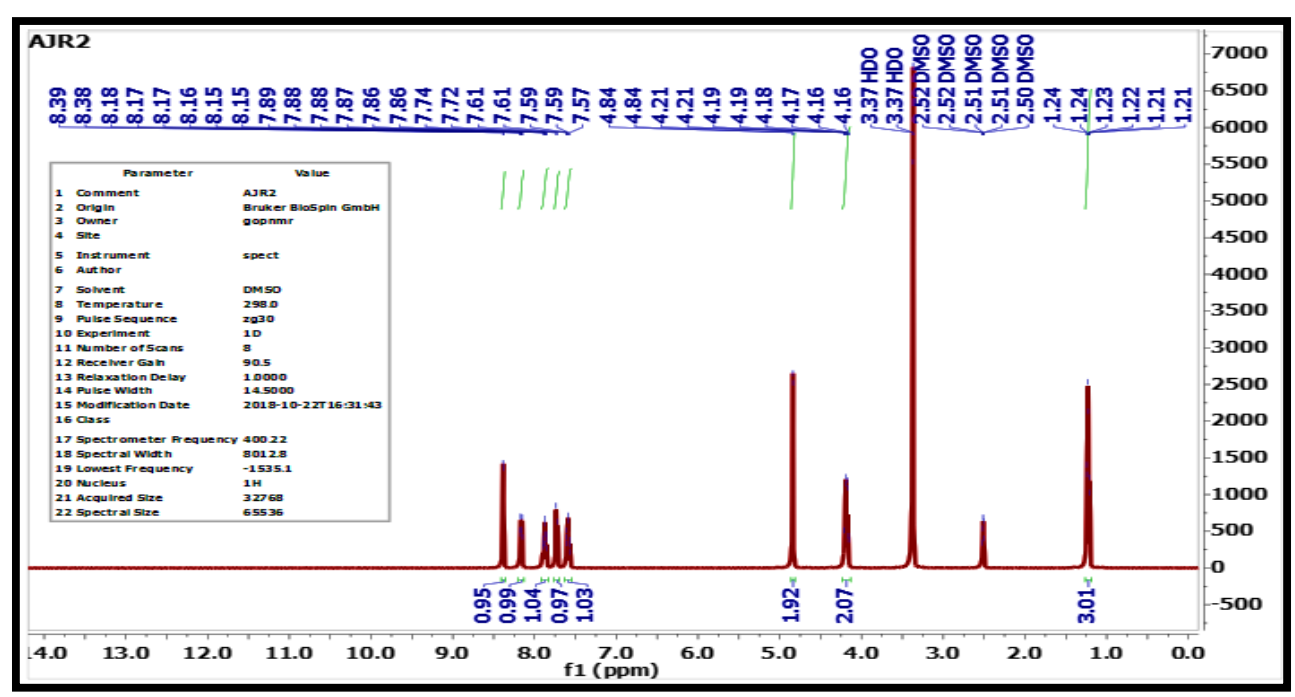

Fig 2: ${ }^{1}$ HNMR spectrum of compound 2.

The ${ }^{13} \mathrm{CNMR}$ spectrum (Fig. 3) [35,36] showed the following chemical shifts, $\delta(\mathrm{ppm})$ at: $14.5\left(\mathrm{CH}_{3}\right)$, $47.72\left(\mathrm{OCH}_{2}\right), 61.78\left(\mathrm{~N}-\mathrm{CH}_{2}\right), 121.74(\mathrm{C} 10), 126.49$ (C5), 127.82 (C6), $135.19(\mathrm{C} 7), 148.43(\mathrm{C} 2, \mathrm{C} 9)$, $160.6(\mathrm{C} 4), 168.41(\mathrm{COO})$. 


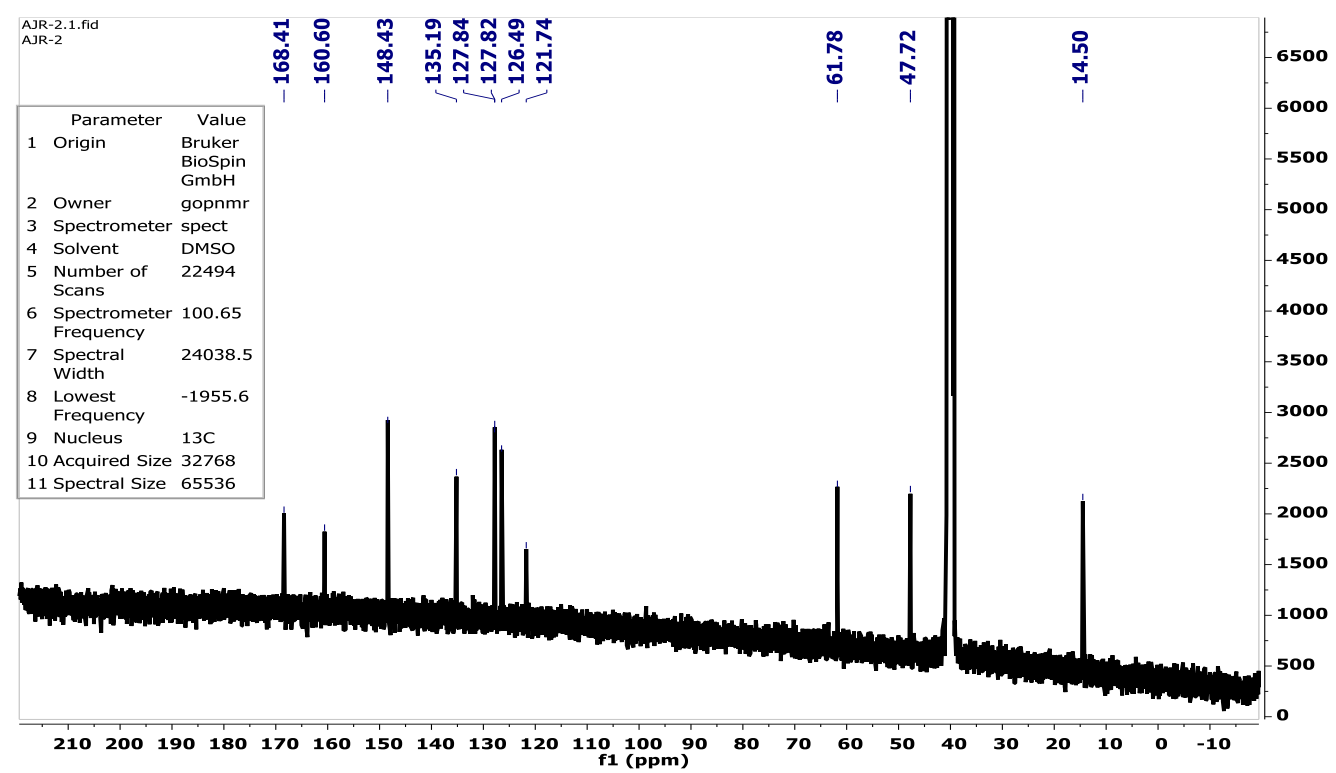

Fig 3: ${ }^{13} \mathrm{C}$ NMR spectrum of compound 2.

The ester (2) was used to synthesize the hydrazide compound (3) and the later compound was considered as a precursor to synthesize the new heterocyclic compounds. The hydrazide (3) was synthesized from the reaction of the ester (2) with hydrazine hydrate (85\%). The (IR, ${ }^{1} \mathrm{HMNR},{ }^{13} \mathrm{CNMR}$ ) [35-37] spectral information was used to confirm the structure of hydrazide compound (3). The infrared spectrum (Fig. 4) exhibited two bands at (1675 and 1652) $\mathrm{cm}^{-1}$ related to $\mathrm{C}=\mathrm{O}$ bond stretching for the amido and hydrazido carbonyl groups respectively. It is worth noting that the appearance of bands at 3287 and $3147 \mathrm{~cm}^{-1}$ related to the amino \& amido N-H bond stretching and the disappearance of the band at $1718 \mathrm{~cm}^{-1}$ for the esteric carbonyl bond stretching indicate the complete conversion of the ester (2) to the hydrazide (3).

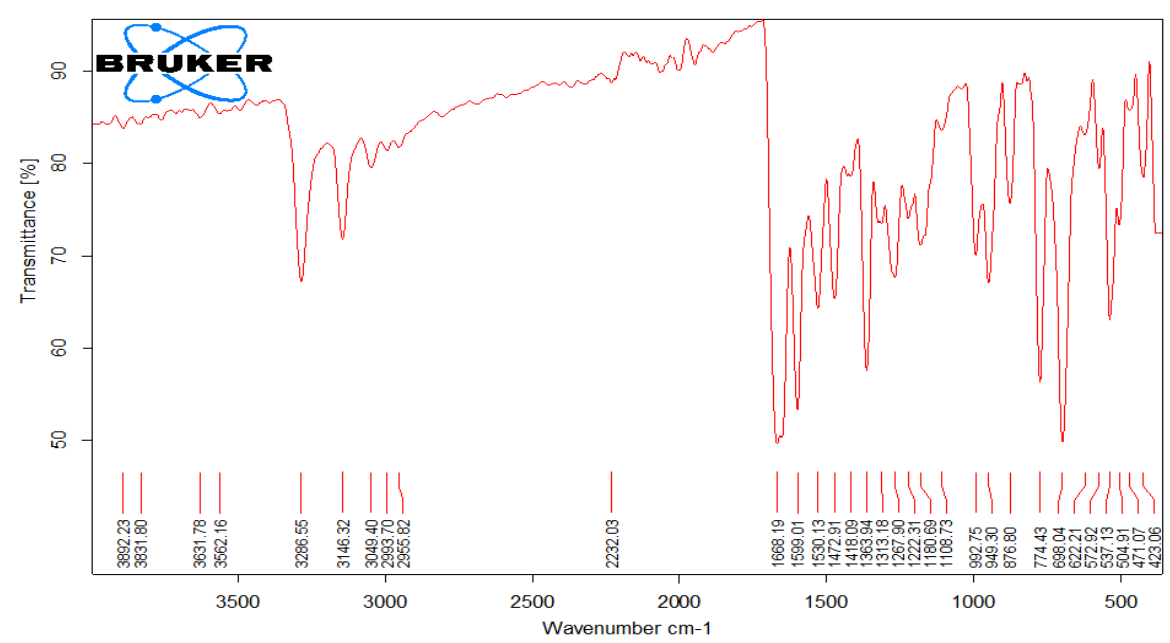

Fig 4: IR spectrum of compound 3.

The ${ }^{1}$ HNMR spectrum (Fig. 5) of the hydrazide (3) showed the following chemical shifts $\delta(\mathrm{ppm})$, at: 3.4 (s, 2H, NH $\left.\mathrm{N}_{2}\right), 4.64$ (s, 2H, $\left.\mathrm{CH}_{2}\right), 7.57$ (t, 1H, H6), 7.72 (d ,1H, H5), 7.85 (t, 1H, H7), 8.15 (d, 1H, $\mathrm{H} 8), 8.32$ (s ,1H, H2), 9.47 (s, 1H, NH), while the 


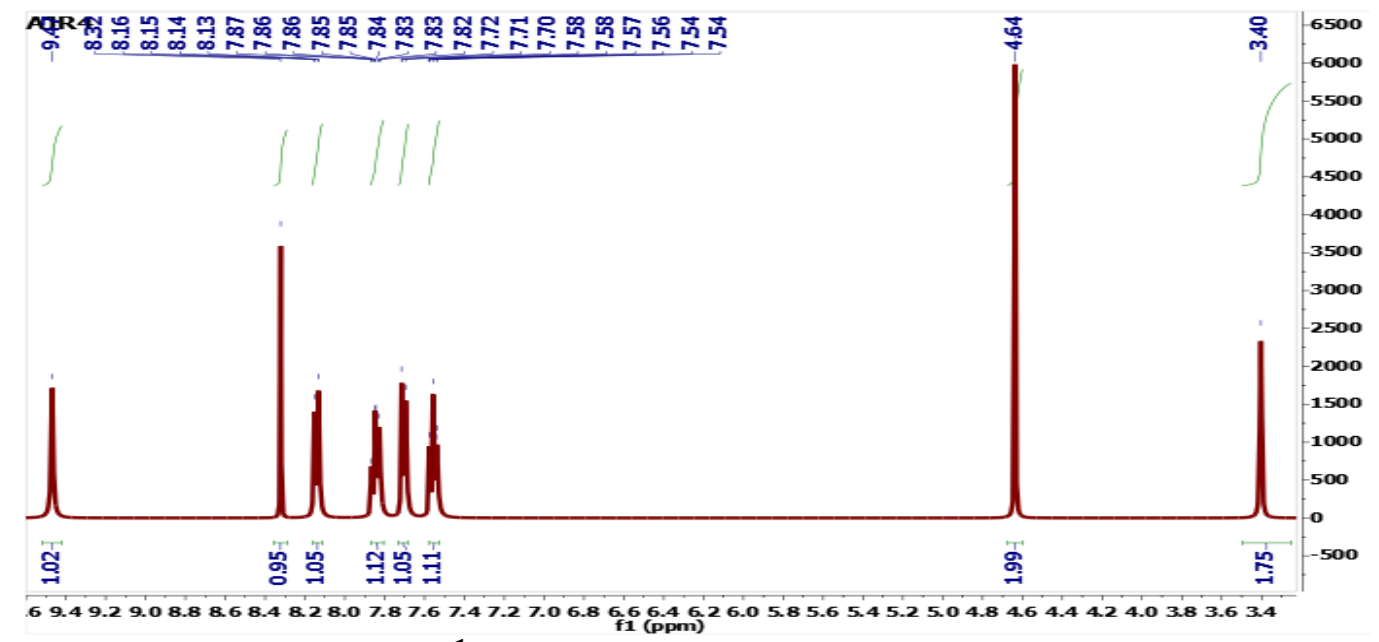

Fig 5: ${ }^{1}$ HNMR spectrum of compound 3.

${ }^{13} \mathrm{C}$ NMR spectrum (Fig. 6) showed the following chemical shifts, $\delta(\mathrm{ppm})$ at: $47.30\left(\mathrm{CH}_{2}\right), 121.99$ (C10), 126.44 (C5), 127.51 (C6), 127.67 (C8), 134.87 (C7), 148.53 (C2), 149.03 (C9), 160.64 (C4), $166.63(\mathrm{C}=\mathrm{O})$.

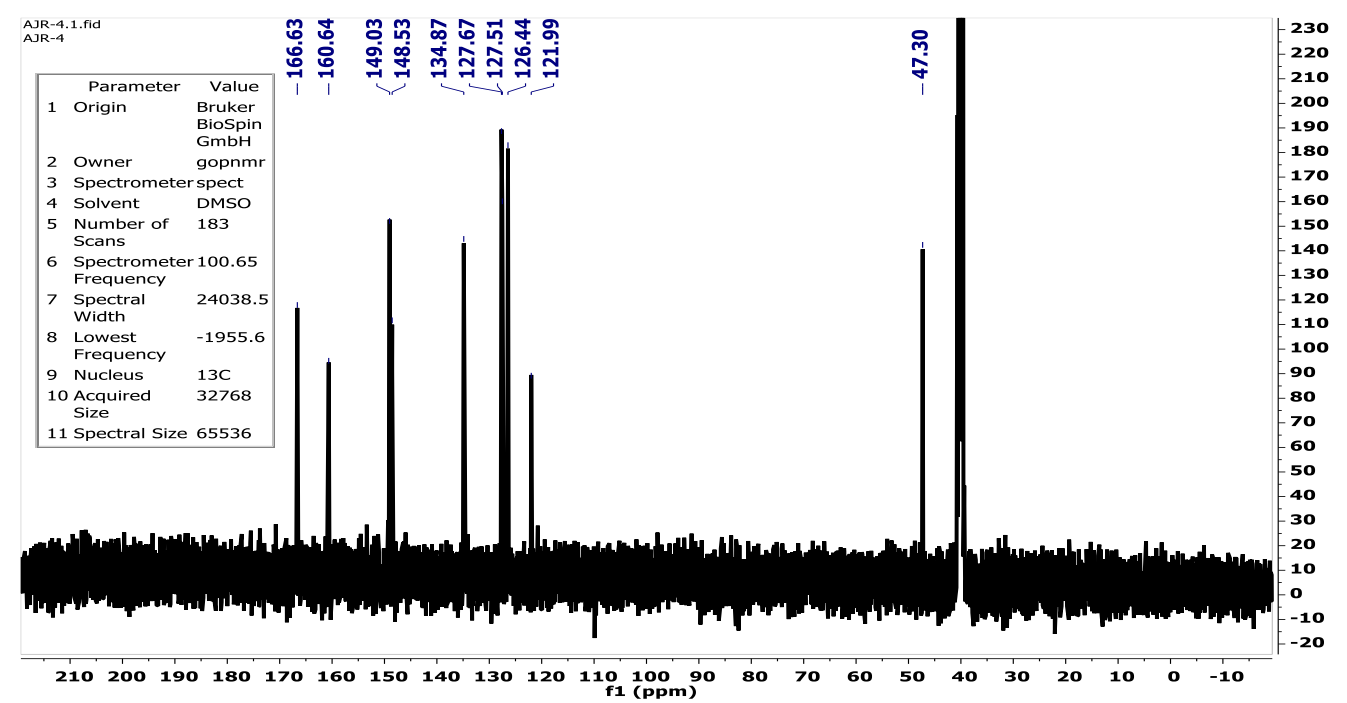

Fig 6: ${ }^{13} \mathrm{C}$ NMR spectrum of compound 3.

The hydrazide (3) was used as a precursor to prepare a series of some new 4-quinazolinones through several synthetic routes. The first one involves the reaction of hydrazide (3) with benzoyl and p-toluoyl chloride to afford N,N'-diacyl hydrazine compounds (4\&5) respectively. The compound (5) was treated with phosphorus oxychloride to produce 1,3,4-oxadiazole compound (6). The IR spectra of compounds (4\&5) showed merging bands at $1664 \& 1662 \mathrm{~cm}^{-1}$ for the carbonyl bond stretching and at $3230,3232 \mathrm{~cm}^{-1}$ related to $\mathrm{N}-\mathrm{H}$ bond stretching. The ${ }^{1} \mathrm{H}$ nuclear magnetic resonance spectrum (Fig. 7 ) of compound (4) showed the following chemical shifts, $\delta(\mathrm{ppm})$ at: $4.76(\mathrm{~s}, 1 \mathrm{H}, \mathrm{phCONH}), 4.86(\mathrm{~s}$, 2H, $\left.\mathrm{CH}_{2}\right), 7.5$ (s, 1H, H6), 7.56 (s, 1H, H5), 7.58 (t, 1H, H7), 7.77-7.96 (m, 5H, ph-H), $8.17(\mathrm{~d}, 1 \mathrm{H}$, $\mathrm{H} 8), 8.4$ (s, 1H, H2), 10.57 (s, 1H, C-CONH). 


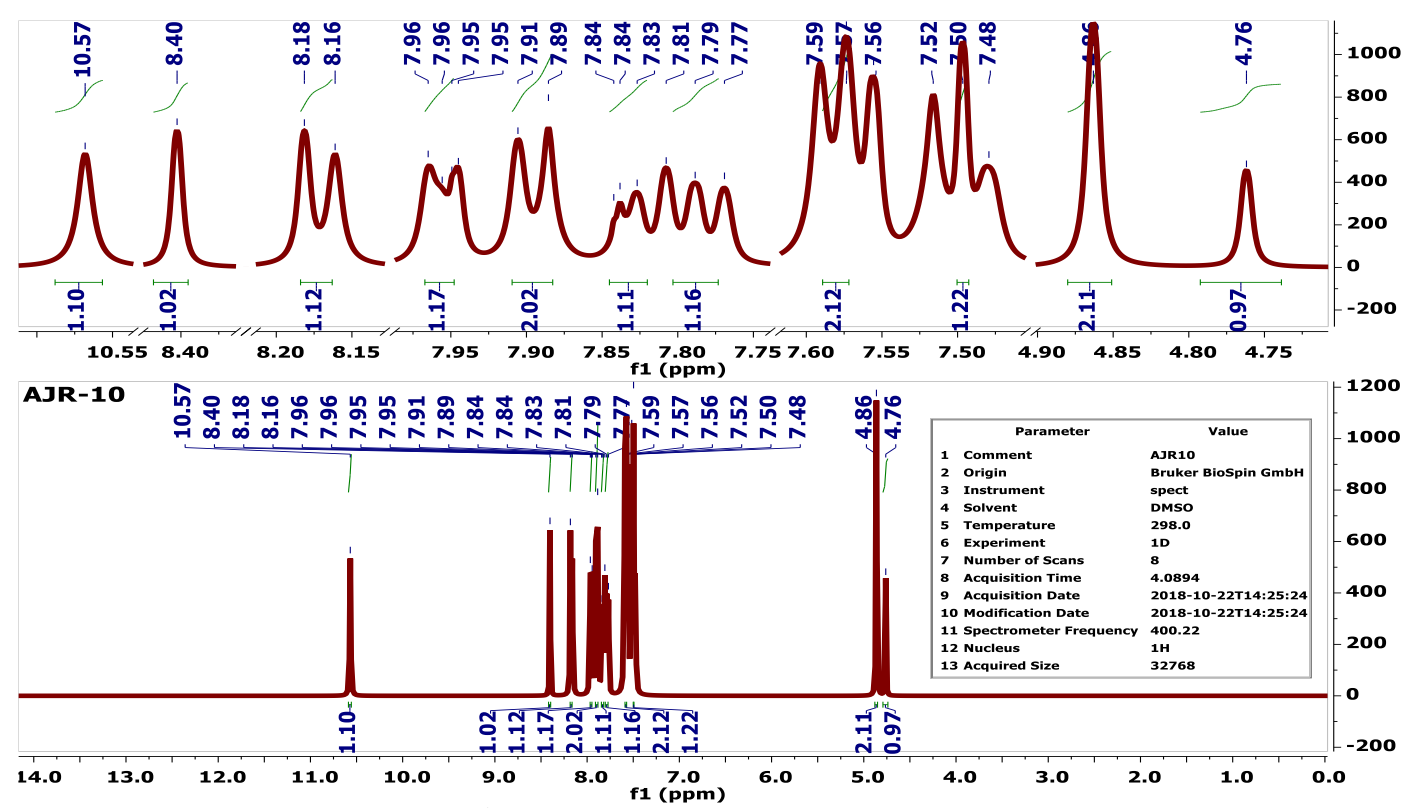

Fig 7: ${ }^{1}$ HNMR spectrum of compound 4.

The infrared spectrum of the derivative (6) exposed the lack of hydrazido carbonyl bond stretching and appearance of the absorption band at $1605 \mathrm{~cm}^{-1}$ for the combination of $\mathrm{C}=\mathrm{C}$ and $\mathrm{C}=\mathrm{N}$ bonds stretching and at 1073 and $1220 \mathrm{~cm}^{-1}$ related to the symmetrical and asymmetrical C-O bond stretching of the oxadiazole moiety in addition to the band at $1655 \mathrm{~cm}^{-1}$ for the carbonyl bond of quinazolinone moiety.

The second route involves the reaction of the hydrazide (3) with formic acid to form the formyl derivatives (7) of the hydrazide. The resultant compound (7) was cyclized in the presence of phosphoryl oxychloride to form the mono-substituted 1,3,4-oxadiazole compound (8). The infrared spectrum of (7) exposed merging bands at $1676 \mathrm{~cm}^{-1}$ for $\mathrm{C}=\mathrm{O}$ bonds, in addition to aromatic bond stretching at $1606 \mathrm{~cm}^{-1}$ and absorption band and $1585 \mathrm{~cm}^{-1}$ related to combination $\mathrm{C}=\mathrm{N}$ and $\mathrm{C}=\mathrm{C}$ bonds stretching. The ${ }^{1} \mathrm{H}$ nuclear magnetic resonance spectrum (Fig. 8) of (7) exhibited the following chemical shifts $\delta(\mathrm{ppm})$, at: $3.42(\mathrm{~s}, 1 \mathrm{H}$, formyl-N- $\mathrm{H}), 4.71\left(\mathrm{~s}, 1 \mathrm{H}, \mathrm{CH}_{2}\right), 7.57(\mathrm{t}, 1 \mathrm{H}, \mathrm{H} 6), 7.71(\mathrm{~d}$, 1H, H5), 7.85 (t, 1H, H7), 8.03 (s, 1H, H13), 8.16 (d, 1H, H8), 8.36 (s, 1H, H2), 10.12 (s, 1H, C$\mathrm{CONH})$.

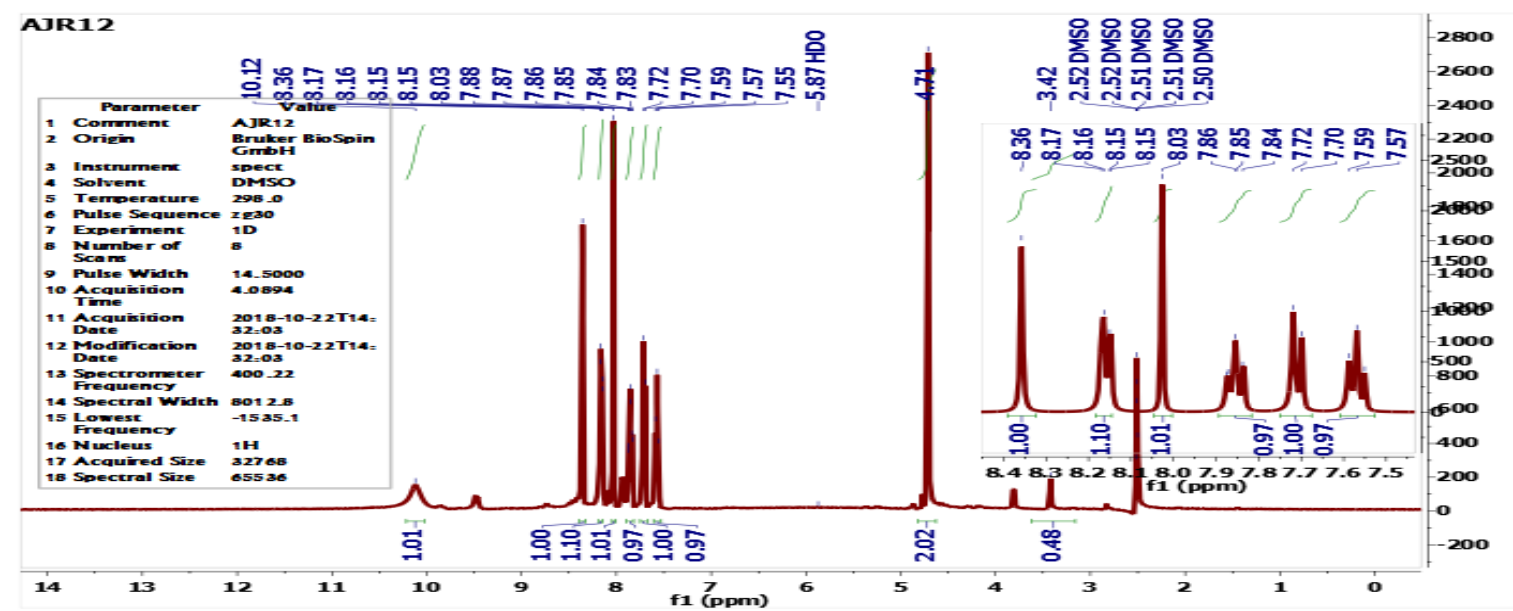

Fig 8: ${ }^{1}$ HNMR spectrum of compound 7.

The structure of 1,3,4-oxadiazole compound (8) was confirmed from its IR spectrum which exposed a disappearance of absorption bands of the hydrazido carbonyl bond stretching and presence of 
absorption bands: at $1672 \mathrm{~cm}^{-1}$ related to the stretching of the quinazolinone $\mathrm{C}=\mathrm{O}$ bond; at $1605 \mathrm{~cm}^{-1}$ for the stretching of the combination of $\mathrm{C}=\mathrm{C}$ and $\mathrm{C}=\mathrm{N}$ bonds and at $1036 \mathrm{~cm}^{-1}$ for stretching of the symmetrical C-O bond for the oxadiazole moiety.

The third route involves the reaction of hydrazide (3) with ammonium thiocyanate to synthesize the thiosemicarbazide derivative (9). This compound showed the following absorption bands in its IR spectrum at $3408,3198 \mathrm{~cm}^{-1}$ for the primary and secondary $\mathrm{N}-\mathrm{H}$ bond stretching respectively, at 1670 and $1655 \mathrm{~cm}^{-1}$ for the cyclic and acyclic amido $\mathrm{C}=\mathrm{O}$ bond stretching and $1167 \mathrm{~cm}^{-1}$ for the stretching of the $\mathrm{C}=\mathrm{S}$ bond. The ${ }^{1} \mathrm{H}$ nuclear magnetic resonance spectrum for the derivative (9) showed the following chemical shifts $\delta$ (ppm), (Fig. 9) at: 4.15 (s, 2H, NH $\mathrm{NH}_{2}, 4.85(\mathrm{~s}, 1 \mathrm{H}, \mathrm{CSNH}), 5.32\left(\mathrm{~s}, 2 \mathrm{H}, \mathrm{CH}_{2}\right)$, 7.57 (t,1H, H6), 7.7 (d, 1H, H5), 7.86 (t, 1H, H7), 8.14 (d, 1H, H8), 8.42 (s,1H, CONH), 8.51 (s,1H, $\mathrm{H} 2)$.

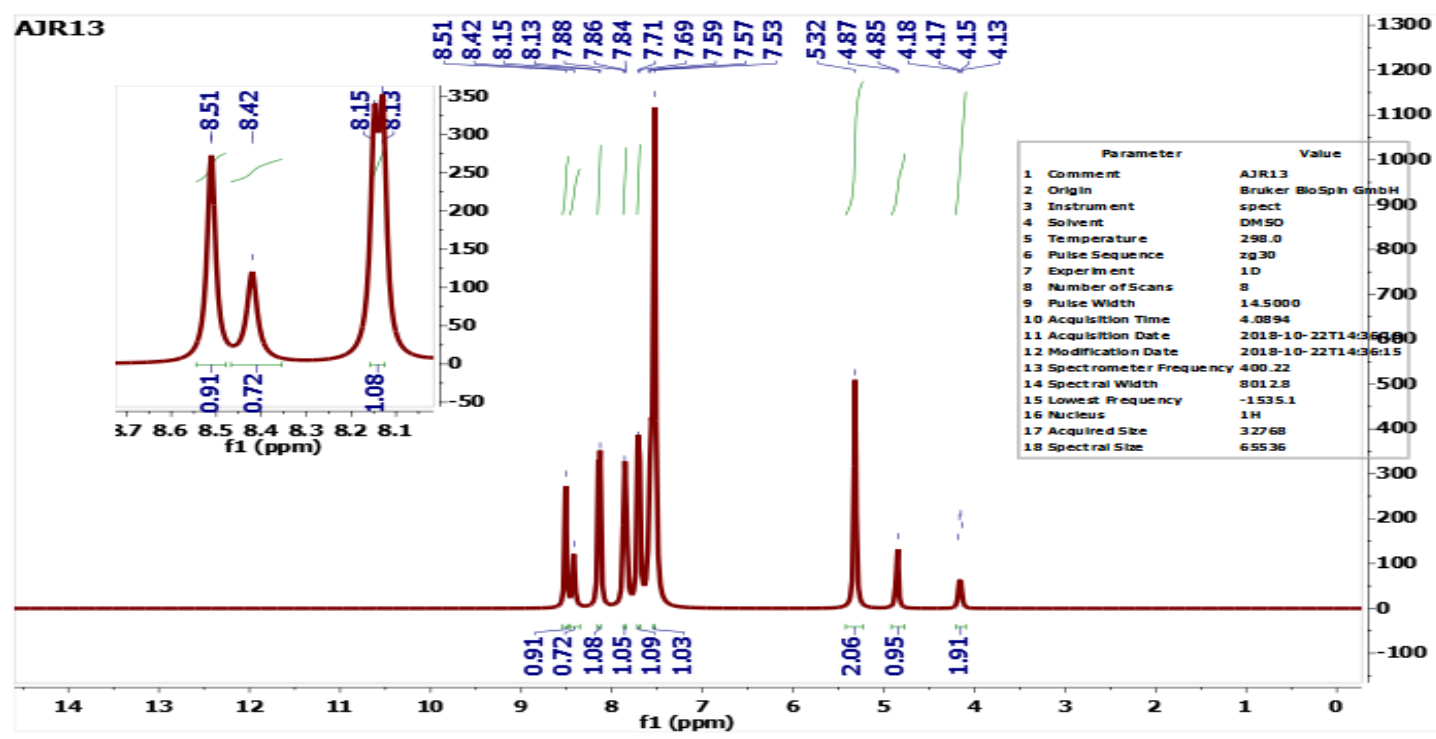

Fig 9: ${ }^{1}$ HNMR spectrum of compound 9.

The fourth route involves the reaction of the hydrazide (3) with organic isothiocyanates (allyl, pchlorophenyl, n-butyl-isothiocyanate) to synthesize 1,4-disubstituted thiosemicarbazides (10-12). These compounds were used as precursors to synthesis new heterocyclic compounds via two synthetic pathways. The first one is the cyclization of compounds (10\&11) under basic condition (4\% sodium hydroxide solution) to form the 1,3,4- triazol-2-thiol derivatives (13\&14), while the second one is the cyclization of compounds (10-12) under acidic condition (concentrated $\mathrm{H}_{2} \mathrm{SO}_{4}$ ) to prepare 2-monosubstituted amino-1,3,4-thiadiazole derivatives (15-17). IR spectra of compounds (10-12) (Table 7) shows absorption peaks: at $1676-1677 \mathrm{~cm}^{-1}$ due to quinazolinone carbonyl bond stretching, at 1653 $1655 \mathrm{~cm}^{-1}$ due to hydrazido carbonyl bond stretching, at $1602-1612 \mathrm{~cm}^{-1}$ for the stretching of the combination of $\mathrm{C}=\mathrm{C}$ and $\mathrm{C}=\mathrm{N}$ bonds and $1193-1216 \mathrm{~cm}^{-1}$ for the $\mathrm{C}=\mathrm{S}$ bond stretching. An additional absorption band for compound (11) appeared at $767 \mathrm{~cm}^{-1}$ related to $\mathrm{C}-\mathrm{Cl}$ bond stretching. 
Table (7): The IR spectral data of compounds (10-12):

\begin{tabular}{|c|c|c|c|c|c|c||}
\hline \multirow{2}{*}{$\begin{array}{c}\text { Compd. } \\
\text { No. }\end{array}$} & $\mathrm{R}$ & \multicolumn{5}{|c|}{ I.R. v (cm-1) } \\
\cline { 2 - 7 } & $\mathrm{N}-\mathrm{H}$ & $\begin{array}{c}\mathrm{C}=\mathrm{O}(\mathrm{Q}) \\
\mathrm{C}=\mathrm{O} \text { (hydrazide) }\end{array}$ & $\begin{array}{c}\mathrm{C}=\mathrm{C} \\
\mathrm{C}=\mathrm{N}\end{array}$ & $\mathrm{C}=\mathrm{S}$ & Others \\
\hline 10 & $-\mathrm{CH}_{2} \mathrm{CH}=\mathrm{CH}_{2}$ & 3130 & $\begin{array}{l}1676 \\
1653\end{array}$ & 1609 & 1193 & $=\mathrm{C}-\mathrm{H} 3030$ \\
\hline 11 & - & 3268 & $\begin{array}{l}1677 \\
1658\end{array}$ & 1602 & 1219 & $\mathrm{C}-\mathrm{Cl} 767$ \\
\hline 12 & $-\left(\mathrm{CH}_{2}\right)_{3} \mathrm{CH}_{3}$ & 3129 & $\begin{array}{l}1677 \\
1654\end{array}$ & 1612 & 1202 & $\mathrm{CH}_{3} 2962$ \\
\hline
\end{tabular}

The proton nuclear magnetic resonance spectrum of (12) showed the following chemical shifts $\delta(\mathrm{ppm})$, (Fig. 10) at: $1.29\left(\mathrm{~m}, 2 \mathrm{H}, \underline{\mathrm{CH}_{2}} \mathrm{CH}_{3}\right), 0.86\left(\mathrm{t}, 3 \mathrm{H}, \mathrm{CH}_{3}\right), 1.51\left(\mathrm{~m}, 2 \mathrm{H}, \underline{\mathrm{CH}}_{2}-\mathrm{CH}_{2} \mathrm{CH}_{3}\right), 3.45$ (s, 1H, CS-NH-Bu), 4.77 (s, 2H, QCH $\left.{ }_{2}\right), 3.54\left(\mathrm{t}, 2 \mathrm{H}, \mathrm{CS}-\mathrm{N}-\mathrm{CH}_{2}\right), 7.57(\mathrm{t}, 1 \mathrm{H}, \mathrm{H} 6), 7.71(\mathrm{~s}, 1 \mathrm{H}, \mathrm{H} 5), 7.73$ (s, 1H, CSNHN), 7.86 (t, 1H, H7), 8.14 (d, 1H, H8), 8.34 (s, 1H, H2), 10.37 (s, 1H, CONHN).

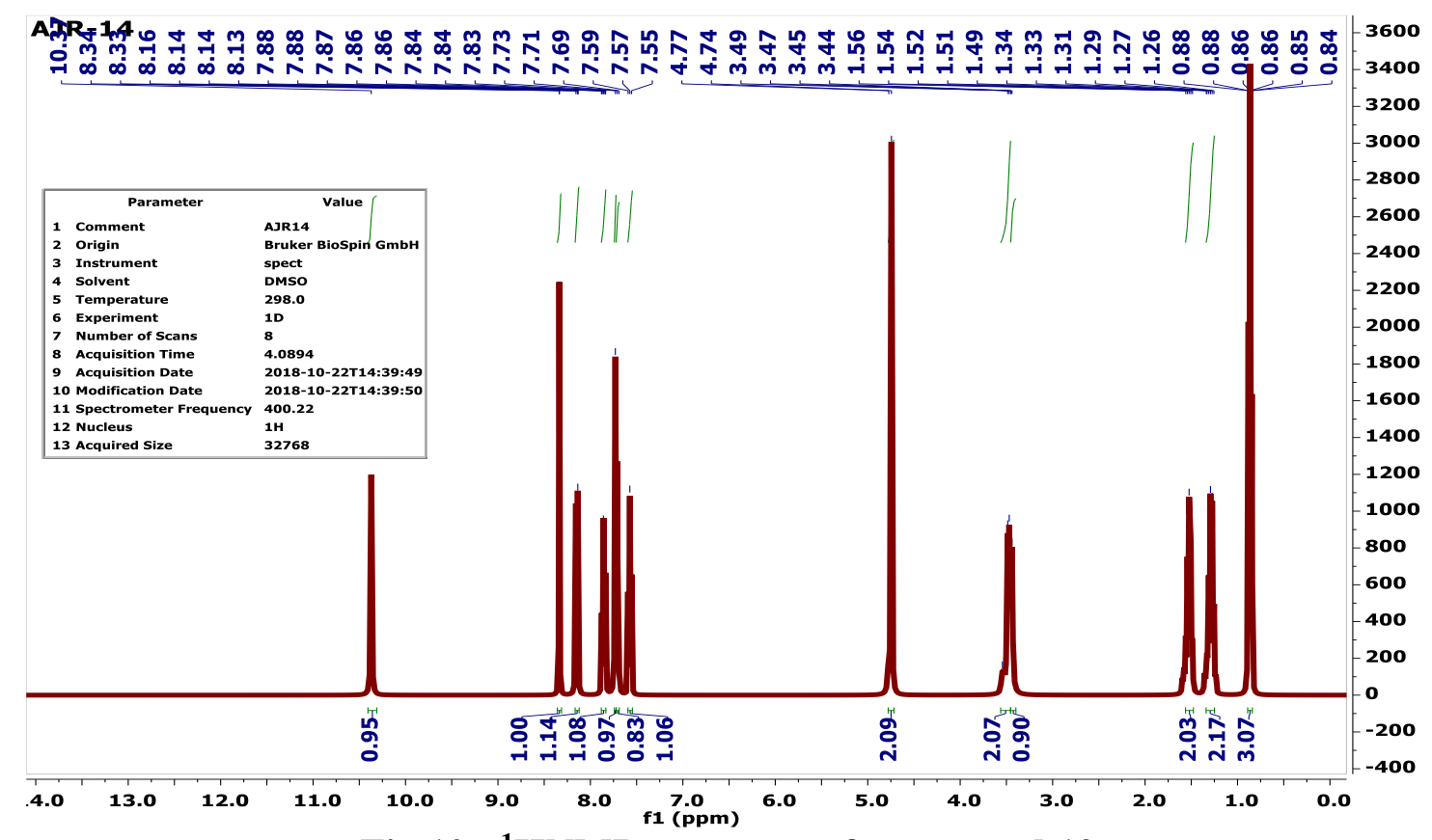

Fig 10: ${ }^{1}$ HNMR spectrum of compound 12.

The infrared spectra are recognized by the absence of the hydrazido carbonyl bond stretching and emersion of the following peaks: at $1670 \mathrm{~cm}^{-1}$ related to quinazolinone carbonyl bond stretching, at $1589,1600 \mathrm{~cm}^{-1}$ for the stretching of the combination of $\mathrm{C}=\mathrm{C}$ and $\mathrm{C}=\mathrm{N}$ bond, and at $1285,1249 \mathrm{~cm}^{-1}$ assigned to the stretching of the thione bond respectively. The compound (13) displays an additional band at $814 \mathrm{~cm}^{-1}$ related to the stretching of the $\mathrm{C}-\mathrm{Cl}$ bond. The IR spectra (Fig. 11) of 1,3,4thiadiazoles (15-17) (Table 8) are recognized by the absence of the thiosemicarbazide $\mathrm{C}=\mathrm{O}$ and $\mathrm{C}=\mathrm{S}$ bond stretching and emersion of bands at $1664-1657 \mathrm{~cm}^{-1}$ related to quinazolinone $\mathrm{C}=\mathrm{O}$ bond stretching, $1602-1607 \mathrm{~cm}^{-1}$ for the combination $\mathrm{C}=\mathrm{N}$ and $\mathrm{C}=\mathrm{C}$ bond stretching in addition to peaks at 690- $702 \mathrm{~cm}^{-1}$ related to the C-S bond stretching. 
Table (8): The IR spectral data of compounds (15-17):

\begin{tabular}{|c|c|c|c|c|c|}
\hline \multirow{2}{*}{ Compd. No. } & \multirow{2}{*}{$\mathbf{R}$} & \multicolumn{4}{|c|}{ I.R. v (cm-1) } \\
\cline { 3 - 6 } & & $\mathbf{C = O}$ & $\begin{array}{r}\mathbf{C}=\mathbf{N} \\
\mathbf{C}=\mathbf{C}\end{array}$ & $\mathbf{N}-\mathbf{H}$ & $\mathbf{C}-\mathbf{S}$ \\
\hline 15 & $-\mathrm{CH}_{2} \mathrm{CH}=\mathrm{CH}_{2}$ & 1661 & 1607 & 3251 & 691 \\
\hline 16 & - & 1657 & 1604 & 3329 & 690 \\
\hline 16 & $-\left(\mathrm{CH}_{2}\right)_{3} \mathrm{CH}_{3}$ & 1664 & 1602 & 3332 & 702 \\
\hline
\end{tabular}

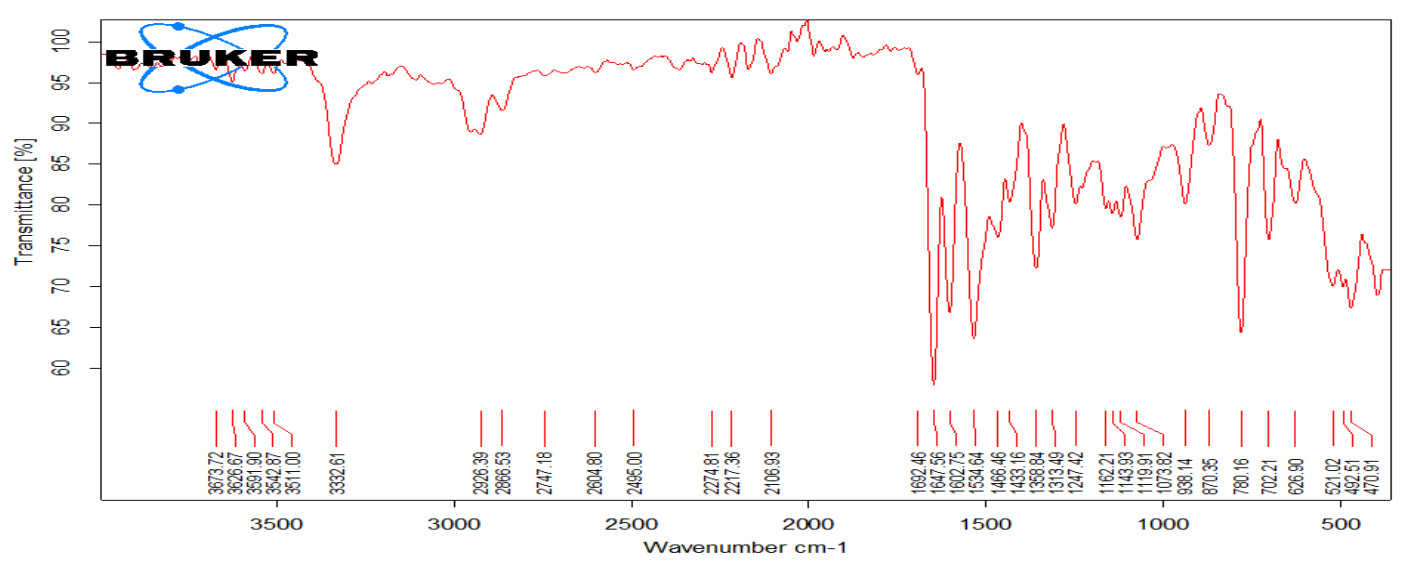

Fig 11: IR spectrum of compound 17

The last route involves the reaction of the hydrazide (3) with an organic isocyanate compound to synthesize 4-(cyclohexyl / p-toluene sulfonyl) semicarbazide compounds $(18,19)$. These compounds were cyclized under basic condition (4\% sodium hydroxide solution) to afford the 1,3,4- triazoles $(20,21)$. The IR spectra of the semicarbazide compounds $(18,19)$ exposed merging bands: at 1667 , $1677 \mathrm{~cm}^{-1}$ for the $\mathrm{C}=\mathrm{O}$ bonds, at $1608,1616 \mathrm{~cm}^{-1}$ for the combination $\mathrm{C}=\mathrm{N}$ and $\mathrm{C}=\mathrm{C}$ bond stretching. The compound (19) showed additional two peaks at $1167 \& 1355 \mathrm{~cm}^{-1}$ for the symmetrical and asymmetrical $\mathrm{SO}_{2}$ bond stretching. The proton nuclear magnetic resonance spectrum of (18) (Fig. 12) displayed the following chemical shifts $\delta(\mathrm{ppm})$, at: 1.14-1.74 $(\mathrm{m}, 11 \mathrm{H}$, cyclohexyl-H), $4.69(\mathrm{~s}, 2 \mathrm{H}$, $\mathrm{CH}_{2}$ ), 6.10 (s, 1H, cyclohexyl-NH), 7.59 (t, 1H, H6), 7.72 (d, 1H, H5), 7.85 (s, 1H, C-CO-NH), 7.87 (t, 1H, H7), 8.15 (d, 1H, H8), 8.35 (s, 1H, H2), 10.09 (s, 1H, NCO-NHN).

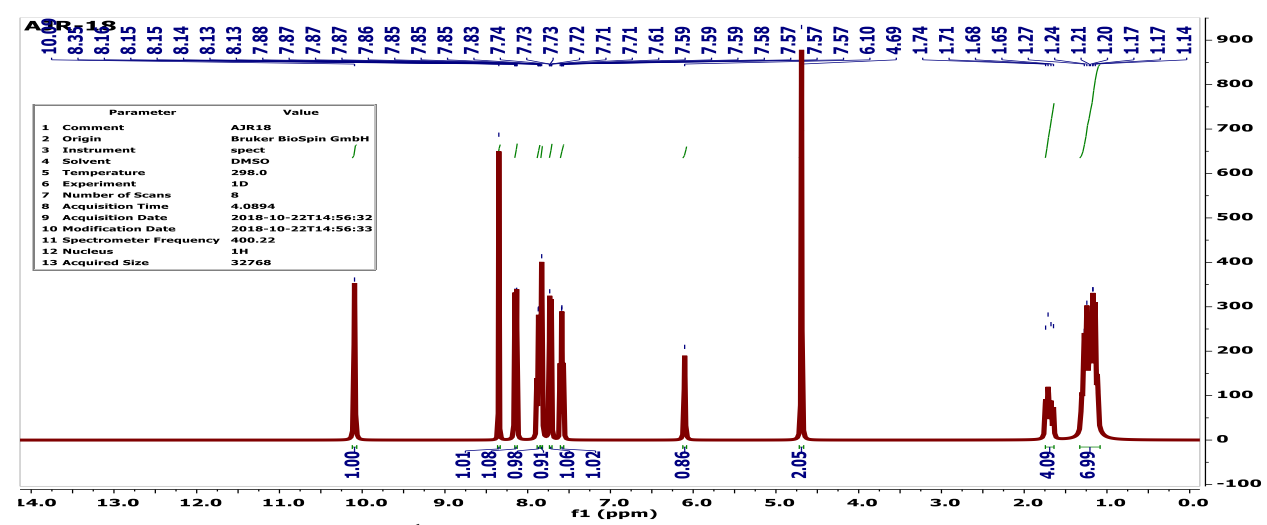

Fig 12: ${ }^{1}$ HNMR spectrum of compound 18.

The IR spectra of the triazoles (20\&21) exposed the disappearance of the peaks of the semicarbazide carbonyl bond stretching and appearance of the quinazolinone $\mathrm{C}=\mathrm{O}$ bond stretching at 1676 and 1684 $\mathrm{cm}^{-1}$ respectively, in addition to the stretching of $\mathrm{C}=\mathrm{N}$ bond of the triazole moiety at $1624 \& 1625 \mathrm{~cm}^{-}$ 
${ }^{1}$ respectively, $\mathrm{O}-\mathrm{H}$ bond stretching at 3399 and $3392 \mathrm{~cm}^{-1}$ and a combination of $\mathrm{C}=\mathrm{C}$ and $\mathrm{C}=\mathrm{C}$ bond stretching at $1551,1546 \mathrm{~cm}^{-1}$. The compound (21) showed additional peaks at $1094 \& 1312 \mathrm{~cm}^{-1}$ related to symmetrical and asymmetrical $\mathrm{SO}_{2}$ bond stretching. The proton nuclear magnetic resonance spectrum of (20) exposed the following chemical shifts $\delta(\mathrm{ppm})$, at: $1.1-3.72(\mathrm{~m}, 11 \mathrm{H}$, cyclohexyl-H), 4.09 (s, 2H, $\left.\mathrm{CH}_{2}\right), 6.5$ (t, 1H, H6), 6.75 (d, 1H, H5), 7.21(d, 1H, H7), 6.68 (d, 1H, H8), 8.83 (s, 1H, $\mathrm{H} 2), 11.86$ (s, 1H, O-H).

\section{REFERENCES}

1. Dohle, W.; Jourdan, F.L.; Menchon, G.; Prota, A.E.; Foster, P.A.; Mannion, P.; Hamel, E.; Thomas, M.P.; Kasprzyk, P.G.; Ferrandis, E.; Steinmetz, M.O.; Leese, M.P.; Potter.B.V.L. J. Med. Chem., 61: 1031-1044 (2018). doi: org/10.1021/acs.jmedchem.7b01474.

2. Rakesh, K.P.; Kumara, H.K.; Manukumar, H.M.; Gowda, D.C. Bioorg. Chem. 87: 252-264 (2019). doi: org/10.1016/j.bioorg.2019.03.038

3. Chandrika P.M., Yakaiah T., Rao A.R., Narsaiah B., Reddy N.C., Sridhar V., Rao, J.V., Eur. J. Med. Chem., 43: 846-852 (2008). doi:10.1016/j.ejmech.2007.06.010

4. Ghorab M.M., Abdel-Gawad S.M., El-Gaby M.S.A., Il Farmaco, 55: 249-255 (2000). doi: org/10.1016/S0014-827X(00)00029-X

5. Mohamed, M.S.; Kamel, M.M.; Kassem, E.M.M.; Abotaleb, N.; Abd El-moez, S.I.; Ahmed, M.F., Eur. J. Med. Chem., 45: 3311-3319 (2010). doi: org/10.1016/j.ejmech.2010.04.014.

6. Abdel Gawad N.M., Georgey H.H., Youssef R.M., El-Sayed N.A., Eur. J. Med. Chem., 45:60586067 (2010). doi: org/10.1016/j.ejmech.2010.10.008

7. Al-Omary F.A.M, Hassan G.S, El-Messery S.M., El-Subbagh H.I., Eur. J. Med. Chem., 47:65-72 (2012). doi: org/10.1016/j.ejmech.2011.10.023

8. Luo H., Yang S., Cai Y., Peng Z., Liu T., Eur. J. Med. Chem., 84: 746-52 (2014). doi: org/10.1016/j.ejmech.2014.07.053

9. Alvarado M., Barceló M., Carro L., Masaguer C.F., Raviña E., Chem. \& Biodivers., 3: 106-117 (2006). doi: org/10.1002/cbdv.200690001

10. Patel N.B., Patel J.C., Arabian J. of Chemistry.; 4: 403-411 (2011). doi:10.1016/j.arabjc.2010.07.005.

11. Saravanan G., Alagarsamy V., Prakash C.R.; Int. J. Pharm. Pharm. Sci., 2(suppl. 4): 83-86 (2010).

12. Al-Omar M.A., El-Azab A.S., El-Obeid H.A., Abdel Hamide S.G., J. Saudi Chem. Soc., 10: 11311148 (2006).

13. Decker M.; Kraus B.; Heilmann, Bioorg. Med. Chem., 16(8): 4252-4261 (2008). doi: org/10.1016/j.bmc.2008.02.083

14. Khalil, M.A.; Soliman, R.; Farghaly, A.M.; Bekhit, A.A., Arch. Pharm., 327(1), 27 (1994). doi: org/10.1002/ardp.19943270105

15. Selvam P., Girija K., Nagarajan G., De Clercq E., Indian J. Pharm. Sci., 67(4): 484-487 (2005).

16. Amin K.M., Kamel M.M., Anwar M.M., Khedr M., Syam Y.M., Eur. J. Med. Chem., 45: 2117 2131 (2010). doi:10.1016/j.ejmech.2009.12.078

17. Alagarsamy V. and Pathak U.S.; Bioorg. \& Med. Chem., 15(10): 3457-3462 (2007).

18. Georgey, H.; Abdel-Gawad, N.; Abbas, S., Molecules, 13(10): 2557-2569 (2008). doi: org/10.3390/molecules13102557

19. Mhaske S.B., and Argade N.P., Tetrahedron, 62: 9787-9826 (2006). doi: 10.1016/j.tet.2006.07.098

20. Wattanapiromsakul C., Forster P.I., Waterman P.G., Phytochemistry, 64(2): 609-615, (2003). doi: 10.1016/s0031-9422(03)00205-X

21. Rzeski, W.; Matysiak, J.; Kandefer-Szerszen, M., Bioorg. \& Med. Chem., 15(9), 3201-3207 (2007). doi: 10.1016/j.bmc.2007.02.041 
22. Jatav, V.; Mishra, P.; Kashaw, S.; Stables, J.P., Eur. J. Med.Chem., 43(9), 1945-1954 (2008). doi: 10.1016/j.ejmech.2007.12.003.

23. Al-Soud, Y.A.; Al-Masoudi, N.A.; Ferwanah, A.S., Bioorg.\& Med. Chem., 11(8): 1701-1708 (2003). doi: 10.1016/S0968-0896(03)00043-9

24. Saad-Aldeen, R.A. and Al-Iraqi, M.A.; The Eurasia Proceedings of Science, Technology, Engineering \& Mathematics (EPSTEM), 7: 93-98 (2019).

25. Mahdi, M.F., Raauf, A.M.R. Mohammed, N.M., Eur. J. chem., 6(4): 461-467 (2015). Doi: org/10.5155/eurjchem.6.4.461-467.1321.

26. Šeršeň, F., Gregáň, F. and Peško, M., Dvoranová, D., Král’ová, K., Matkovičová, Z., and Gregáň , J., Donovalová, J., Molecules., 20(8): 14139-14154 (2015). org/10.3390/molecules200814139

27. Diadone, G., Raffa, D. Plescia, F., Maggio, B., Roccaro, A., ARKIVOC., (xi): 227-235(2002). dx.doi.org/10.3998/ark.5550190.0003.b20

28. Verma, G., Khan, M. F., Akhtar, W., Alam, M.M., and Shaquiquzzaman, M., Int. J. Pharm. Chem. \& Anal., 4(2): 37-42 (2017). doi:10.18231/2394-2797.2017.0010

29. Daoud, Kh. M., Raf. J. Sci.,12(4): 29-34 (2001).

30. Daoud, K.M., Mohamed, S.R., Al-Niami, N.M.Z., J. Edu. \& Sci.22(37): 1-10 (2009).

31. Mobinikhaledi, A., Foroughifar, N., Khanpour, M. and Ebrahimi, S., Eur. J. chem., 1(1): 33-36 (2010). doi:10.5155/eurjchem.1.1.33-36.5

32. Abdel-Wahab, B.F., Mohamed, S.F., Amr, A.E., Abdalla, M.M., Monatsh. Chem., 139: 1083-1090 (2008). doi:10.1007/s00706-008-0896-2

33. Fathy, N.M., Abdel-Motti, F., Abdel-Megeid, F.M.E., Commun. Fac. Sci. Univ. Ank., Series B.,37: 1-8 (1991). doi: org/10.1501/Commub_0000000435

34. Crews, Ph.; Rodriguez, J.; Jaspars, M., "Organic Structure Analysis", New York, Oxford, Oxford University Press, (1998).

35. Parikh, V.M. " Absorption Spectroscopy of Organic Molecules" Addison-Wesley Publishing Company Inc. USA. (1974).

36. Levy, G. C., Lichter, R. L., Nelson, G. L., "Carbon-13 Nuclear Magnetic ResonanceSpectroscopy". John Wiley \& Sons Ltd., New York, Chichester, Brisbane, Toronto (1980). 